\title{
Penerapan Keselamatan Pasien Oleh Perawat Di Rumah Sakit
}

\author{
Miranda Sipayung
}

\section{Latar Belakang}

Keselamatan pasien (patient safety) adalah dasar dari pelayanan kesehatan yang baik. Keselamatan pasien juga menjadi salah satu indikator dalam menilai akreditas institusi pelayanan kesehatan, oleh karena itu keselamatan pasien sangat penting. Namun, jika ditinjau dari insiden keselamatan pasien, keselamatan pasien di berbagai tingkat pelayanan kesehatan masih buruk, baik secara global maupun nasional.

Keselamatan adalah suatu system yang membuat asuhan pasien lebih aman, meliputi assasmen resiko, identifikasi dan pengelolaan resiko pasien, peporan dan analisis insiden, kemampuan belajar dari insiden dan tindak lanjutnya, serta implementasi solusi untuk meminimalkan timbulnya resiko dan mencegah terjadinya cedera yang disebabkan oleh kesalahan akibat melaksanakan suatu tindakan atau tidak mengambil tindakan yang seharusnya. Suatu jaminan segala tindakan dan aktivitas yang berhubungan dengan pasien yang dilakukan oleh petugas kesehatan agar berlangsung dengan aman. Memberikan citra yang besar, tanggung jawab sosial moral serta kinerja petugas kesehatan agar mutunya menjadi lebih baik.

Rumah Sakit (RS) adalah institusi pelayanan kesehatan bagi masyarakat dengan karateristik tersendiri yang dipengaruhi oleh perkembangan ilmu pengetahuan kesehatan, kemajuan teknologi, dan kehidupan sosial ekonomi masyarakat yang harus tetap mampu meningkatkan pelayanan yang lebih bermutu dan terjangkau oleh masyarakat agar terwujud derajat kesehatan yang setinggitingginya, seperti yang dijelaskan dalam UndangUndang Kesehatan Nomor 36 Tahun 2009 dan Undang-Undang Rumah Sakit Nomor 44 Tahun 2009 bahwa

rumah sakit wajib melaksanakan pelayanan kesehatan yang aman, bermutu, anti diskriminasi dan efektif, dengan mengutamakan kepentingan pasien. Rumah sakit wajib memenuhi hak pasien memperoleh keamanan dan keselamatan selama dalam perawatan di rumah sakit.

\section{Metode}

Metode yang digunakan adalah suatu Teknik pengumpulan data atau informasi dengan melakukan analisis dari berbagai jurnal yg ada di google, eksplorasi, kajian bebas yang relevan 
yang berfokus pada penerapan keselamatan pasien oleh perawat di Rumah Sakit dengan menggunakan 10 referensi dari jurnal dan Buku ajar .

\section{Hasil}

Berdasarkan hasil pencarian yang saya dapat menyatakan bahwa dalam menerapkan patient safety di rumah sakit : Apabila dilihat berdasarkan masing- masing sasaran didapatkan bahwa semua sasaran keselamatan pasien hamper seluruhnya berada pada kategori kurang baik. Sedangkan pada hasil penelitian tersebut pada sasaran pengendalian infeksi perawat dan dokter memiliki pengetahuan yang lebih baik dibanding sasaran yang lainnya. Berbeda dengan hasil penelitian yang dilakukan oleh Aruningrum (2014) bahwa pengetahuan perawat dalam Sasaran Keselamatan Pasien didapatkan 97\% perawat mengetahui identifikasi pasien, $88 \%$ perawat mengetahui tentang komunikasi efektif, 99\% perawat mengetahui tentang penggunaan obat, 95\% perawat mengetahui tentang pengendalian infeksi, dan $70 \%$ perawat mengetahui pengendalian risiko jatuh pada pasien di rumah sakit.

Hubungan caring perawat dengan kepuasan pasien menunjukan bahwa terdapat kecenderungan, semakin perilaku caring perawat baik menunjukan bahwa terjadi kepuasan yang tinggi. Perilaku perawat yang kurang caring akan mempengaruhi kepuasan pasien yang rendah (Jones.2008) menjelaskan bahwa untuk menciptakan sebuah kepercayaan pasien kepada dokter atau perawat adalah dengan menciptakan waktu bersama dengan pasien. Hal ini sejalan dengan penelitian yang dilakukan oleh Sukesi. (2013).

Mengenai upaya peningkatan caring perawat terhadap kepuasan pasien diruang rawat inap RS Permata Medika Semarang. Didapatkan hasil perawat yang berprilaku caring kepada pasien memberikan kepuasan pasien saat dirawat dirawat. Hasil penelitian ditemukan pernyataan yang menujukan semua partisipan kurang mengerti dengan kondisi penyakit yang dialami. Setelah sakit baru berobat, dan sugesti yang telah dilakukan adalah pengobatan tradisional. Keadaan yang terjadi pada Partisipan adalah datang ke Rumah Sakit dengan kondisi yang membutuhkan tenaga kesehatan. Pola kebiasaan masyarakat yaitu membutuhkan perawatan bila dalam kondisi sakit parah. Keadaan tersebut menurut Kristina, \& Sudjaswadi. (2007) masyarakat mencari pengobatan antara lain ke puskesmas, paramedis, dokter praktik, rumah sakit, balai pengobatan, dan pengobatan tradisional.

Kepuasan pasien sangat dipengaruhi oleh sikap dan pendekatan perawat di rumah sakit kepada pasien, mutu pelayanan keperawatan yang diterima pasien. Tindakan perawat dalam hal ini adalah tindakan yang berkaitan dengan 6 standar keselamatan pasien. 


\section{Pembahasan}

Keselamatan Pasien (patient safety) merupakan isu global dan nasional bagi rumah sakit, komponen penting dari mutu layanan kesehatan, prinsip dasar dari pelayanan pasien dan komponen kritis dari manajemen mutu (WHO, 2014). Ada lima isu penting yang terkait dengan keselamatan (safety) di rumah sakit yaitu: keselamatan pasien (patient safety), keselamatan pekerja atau petugas kesehatan, keselamatan bangunan dan peralatan di rumah sakit, keselamatan lingkungan (green productivity) dan keselamatan bisnis rumah sakit. Ke lima aspek keselamatan tersebut sangatlah penting untuk dilaksanakan di setiap rumah sakit. Harus diakui kegiatan institusi rumah sakit dapat berjalan apabila ada pasien. Karena itu keselamatan pasien merupakan prioritas utama untuk dilaksanakan dan hal tersebut terkait dengan isu mutu dan citra perumahsakitan. Salah satu masalah umum yang terjadi dalam pemberian pelayanan di bidang kesehatan adalah masalah yang berkaitan dengan keselamatan pasien.

Penelitian yang dilakukan oleh IBEAS (Iberoamerican Study of Adverse Events) pada tahun 2011 yang dilakukan di 58 rumah sakit yang tersebar di Argentina, Colombia, Costa Rica, Mexico dan Peru serta melibatkan 11.379 pasien rawat inap mendapatkan hasil dari jumlah tersebut, 1.191 memiliki setidaknya satu insiden keselamatan pasien yang berkaitan dengan perawatan yang diterima dari pelayanan kesehatan.

Perawat sebagai ujung tombak pemberi pelayanan kesehatan merupakan hal yang penting untuk dikaji dalam rangka mempertahankan dan meningkatkan mutu pelayanan kesehatan. Kinerja yang baik merupakan jembatan dalam menjawab kualitas pelayanan kesehatan yang diberikanterhadap pasien baik yang sakit maupun yang sehat (Murdyastuti, 2010). Perawat harus sadar akan perannya sehingga dapat secara aktif ikut berpartisipasi untuk mewujudkan keselamatan pasien.

Keselamatan pasien (patient safety) adalah dasar dari pelayanan kesehatan yang baik. Keselamatan pasien juga menjadi salah satu indikator dalam menilaiakreditas institusi pelayanan kesehatan, oleh karena itu keselamatan pasien sangat penting. Namun, jika ditinjau dari insiden keselamatan pasien, keselamatan pasien di berbagai tingkat pelayanan kesehatan masih buruk, baik secara global maupun nasional.

Keselamatan adalah suatu system yang membuat asuhan pasien lebih aman, meliputi assasmen resiko, identifikasi dan pengelolaan resiko pasien, peporan dan analisis insiden, kemampuan belajar dari insiden dan tindak lanjutnya, serta implementasi solusi untuk meminimalkan timbulnya resiko dan mencegah terjadinya cedera yang disebabkan oleh kesalahan akibat 
melaksanakan suatu tindakan atau tidak mengambil tindakan yang seharusnya. Suatu jaminan segala tindakan dan aktivitas yang berhubungan dengan pasien yang dilakukan oleh petugas kesehatan agar berlangsung dengan aman. Memberikan citra yang besar, tanggung jawab sosial moral serta kinerja petugas kesehatan agar mutunya menjadi lebih baik.

Rumah Sakit (RS) adalah institusi pelayanan kesehatan bagi masyarakat dengan karateristik tersendiri yang dipengaruhi oleh perkembangan ilmu pengetahuan kesehatan, kemajuan teknologi, dan kehidupan sosial ekonomi masyarakat yang harus tetap mampu meningkatkan pelayanan yang lebih bermutu dan terjangkau oleh masyarakat agar terwujud derajat kesehatan yang setinggitingginya, seperti yang dijelaskan dalam UndangUndang Kesehatan Nomor 36 Tahun 2009 dan Undang-Undang Rumah Sakit Nomor 44 Tahun 2009 bahwa rumah sakit wajib melaksanakan pelayanan kesehatan yang aman, bermutu, anti diskriminasi dan efektif, dengan mengutamakan kepentingan pasien. Rumah sakit wajib memenuhi hak pasien memperoleh keamanan dan keselamatan selama dalam perawatan di rumah sakit.

Keselamatan Pasien (patient safety) merupakan isu global dan nasional bagi rumah sakit, komponen penting dari mutu layanan kesehatan, prinsip dasar dari pelayanan pasien dan komponen kritis dari manajemen mutu (WHO, 2014). Ada lima isu penting yang terkait dengan keselamatan (safety) di rumah sakit yaitu: keselamatan pasien (patient safety), keselamatan pekerja atau petugas kesehatan, keselamatan bangunan dan peralatan di rumah sakit, keselamatan lingkungan (green productivity) dan keselamatan bisnis rumah sakit. Ke lima aspek keselamatan tersebut sangatlah penting untuk dilaksanakan di setiap rumah sakit. Harus diakui kegiatan institusi rumah sakit dapat berjalan apabila ada pasien. Karena itu keselamatan pasien merupakan prioritas utama untuk dilaksanakan dan hal tersebut terkait dengan isu mutu dan citra perumahsakitan. Salah satu masalah umum yang terjadi dalam pemberian pelayanan di bidang kesehatan adalah masalah yang berkaitan dengan keselamatan pasien. Penelitian yang dilakukan oleh IBEAS (Iberoamerican Study of Adverse Events) pada tahun 2011 yang dilakukan di 58 rumah sakit yang tersebar di Argentina, Colombia, Costa Rica, Mexico dan Peru serta melibatkan 11.379 pasien rawat inap mendapatkan hasil dari jumlah tersebut, 1.191 memiliki setidaknya satu insiden keselamatan pasien yang berkaitan dengan perawatan yang diterima dari pelayanan kesehatan.

Perawat sebagai ujung tombak pemberi pelayanan kesehatan merupakan hal yang penting untuk dikaji dalam rangka mempertahankan dan meningkatkan mutu pelayanan kesehatan. Kinerja yang baik merupakan jembatan dalam menjawab kualitas pelayanan kesehatan yang 
diberikan terhadap pasien baik yang sakit maupun yang sehat (Murdyastuti, 2010). Perawat harus sadar akan perannya sehingga dapat secara aktif ikut berpartisipasi untuk mewujudkan keselamatan pasien.

Dukungan sosial sangat dibutuhkan oleh pasien terutama saat menjalani pengobatan. Terjadi proses penyesuaian diri terhadap penyakit sangat dipengaruhi oleh ketersediaan sumber dukungan dan sosial (Catz. 2000; DiMatteo, \& Kravitz. 1991). Salah satu bentuk dukungan yang dibutuhkan di lingkungan sosial adalah dukungan emosional berupa dihargai dan dicintai. Seseorang yang mengalami ataupun menghadapi masalah sangat membutuhkan dukungan keluarga (Ratna. 2010). Dukungan keluarga sebagai strategi preventif untuk mengurangi stress dimana pandangan hidup menjadi luas, dan tidak mudah stress. Dukungan keluarga adalah sikap, tindakan dan penerimaan keluarga terhadap penderita sakit.

Menurut Suryabrata (2008), bahwa pada dasarnya belajar akan menimbulkan perubahan perilaku baik aktual maupun potensial. Sejalan dengan hal ini, Robbins (2001) dengan jelas mengungkapkan pola penerimaan pengetahuan dan pembelajaran yang ada dalam kegiatan pelatihan staf merupakan hal yang penting untuk diperhatikan dalam proses pemberian pelatihan. Perubahan perilaku yang didasari pada perubahan kemampuan kognitif individu dipengaruhi oleh banyak hal antara lain; proses emosional, internal, dan pribadi. Kombinasi pengalaman dan konseptualisasi merupakan kondisi pembelajaran yang paling baik bagi staf

Perbedaan pemahaman sebelum dan setelah pelatihan yang diberikan terhadap perawa pelaksana pada kelompok eksperimen mengenai penerapan keselamatan pasien dalam pelayanan keperawatan merupakan peningkatan hasil yang diharapkan melalui pemberian intervensi berupa pelatihan. Hal ini sejalan pendapat Rivai dan Sagala (2009) yang menyatakan jika kemampuan peserta pelatihan meningkat secara bermakna, yang artinya program pelatihan secara aktual bisa menyebabkan terjadi perbedaan kemampuan. Program pelatihan dapat dikatakan berhasil apabila peningkatan kemampuan dapat memenuhi kriteria evaluasi dan dapat diubah ke pekerjaan serta mengakibatkan perubahan sikap yang diukur dengan meningkatkan pelaksanaan pekerjaan.

\section{Penutup}

Keselamatan Pasien (KP) adalah suatu sistem dimana rumah sakit membuat asuhan pasien lebih aman,mencegah terjadinya cidera yang disebabkan oleh kesalahan akibat melaksanakan suatu tindakan atau tidak mengambil tindakan yang seharusnya diambil. Pada prinsipnya pelaksanaan tujuh langkah menuju keselamatan pasien sesuai dengan standar Kementerian 
Kesehatan. Walaupun pencanangan keselamatan pasien, tetapi pelaksanaan masih beragam di Rumah Sakit Indonesia. Dengan melakukan penelitian yang membuktikan bahwa setelah dilakukan pelatihan keselamatan pasien terhadap perawat pelaksana menyebabkan peningkatan pemahaman perawat pelaksana tentang penerapan keselamatan pasien yang dipengaruhi perubahan kognitif selama proses pelatihan.

\section{Referensi}

Anugraihini,C., Sahar,J., Mustikasari. (2010). Kepatuhan Perawat Menerapkan Pedoman Patient Safety Berdasarkan Faktor Individu Dan Organisasi. Jurnal Keperawatan Indonesia.13,(3):139-144.

Arruum,D.,Salbiah.,Manik,M. (2015).Pengetahuan Tenaga Kesehatan Dalam Sasaran Keselamatan Pasien Di Rumah Sakit Universitas Sumatera Utara: Idea Nursing Journal.6,(2):14.

Eka Ernawati \& Milawati Lusiani.2019.Studi Fenomenologi: Pelaksanaan Patient Center Care Perspektif Pasien dan Perawat di RS dr. Dradjat Prawiranegara Serang.Serang: Faletehan Health Journal, 6 (3) (2019) 83-90 ISSN 2088-673X | e-ISSN 2597-8667

Firawati., Pabuty. A., \& Putra, A. S. (2012). Pelaksanaan Program Keselamatan Pasien di RSUD Solok. Jurnal Kesehatan Masyarakat, 6 (2), 73-79.

Insani, T. H. N., \& Sundari. S. (2018). Analisis Pelaksanaan Keselamatan Pasien Oleh Perawat. Journal of Health Studies, 2 (1), 84-95.

Ns. Nining Sriningsih,Endang Marlina \& Ns. Nining Sriningsih. 2020.Pengetahuan Penerapan Keselamatan Pasien (Patient Safety) Pada Petugas Kesehatan. Tangerang : Jurnal Kesehatan, Vol. 9 No. 1 (2020). ISSN 2086-9266 e-ISSN 2654-587xDOI 10.37048/kesehatan.v9i1.120

Rivai, F., Sidin, A. I., \& Kartika, I.(2016). Faktor yang Berhubungan dengan Implementasi Keselamatan Pasien di RSUD Ajjappannge Soppeng Tahun 2015. Jurnal Kebijakan Kesehatan Indonesia,5 (4), 152-157.

Simamora, R.H. (2019). The Influence Of Training HandOver Based SBAR Communication For Improving Patient Safety, Indian Journal Of Public Health Research \& Development, 9 jilid 10, 1280-1285.

Simamora, R. H. (2018). Buku ajar keselamatan pasien melalui timbang terima pasien berbasis komunikasi efektif: SBAR. Medan: USUpress. 
Widiasari., Handiyani. H., \& Novieastari. (2019). Kepuasan Pasien Terhadap Penerapan Keselamatan Pasien di Rumah Sakit. Jurnal Keperawatan Indonesia, 22 (1), 43-52.

Yulia, S., Hamid, A. Y. S., \& Mustikasari. (2012). Peningkatan Pemahaman Perawat Pelaksana Dalam Penerapan Keselamatan Pasien Melalui Pelatihan Keselamatan Pasien. Jurnal Keperawatan Indonesia, 15 (3), 185-192.

Yusuf, M. (2017). Penerapan Patient Safety di Ruang Rawat Inap Rumah Sakit Umum Daerah Dr. Zainoel Abidin. Jurnal Ilmu Keperawatan, 5 (1), 84-89. 